\title{
Measurements meet human observations: integrating distinctive ways of knowing in the Pamir Mountains of Tajikistan to assess local climate change
}

\author{
Isabell Haag ${ }^{1}$ (D) Karim-Aly Kassam ${ }^{2}$ (D) $\cdot$ Thomas Senftl $^{1} \cdot$ Harald Zandler $^{1,3}$ (D) \\ Cyrus Samimi $^{1,3}$ (D)
}

Received: 25 May 2020 / Accepted: 6 January 2021/Published online: 02 March 2021

(C) The Author(s) 2021

\begin{abstract}
In mountain environments dimensions of climate change are unclear because of limited availability of meteorological stations. However, there is a necessity to assess the scope of local climate change, as the livelihood and food systems of subsistence-based communities are already getting impacted. To provide more clarity about local climate trends in the Pamir Mountains of Tajikistan, this study integrates measured climate data with community observations in the villages of Savnob and Roshorv. Taking a transdisciplinary approach, both knowledge systems were considered as equally pertinent and mutually informed the research process. Statistical trends of temperature and snow cover were retrieved using downscaled ERA5 temperature data and the snow cover product MOD10A1. Local knowledge was gathered through community workshops and structured interviews and analysed using a consensus index. Results showed, that local communities perceived increasing temperatures in autumn and winter and decreasing amounts of snow and rain. Instrumental data records indicated an increase in summer temperatures and a shortening of the snow season in Savnob. As both knowledge systems entail their own strengths and limitations, an integrative assessment can broaden the understanding of local climate trends by (i) reducing existing uncertainties, (ii) providing new information, and (iii) introducing unforeseen perspectives. The presented study represents a time-efficient and global applicable approach for assessing local dimensions of climate change in data-deficient regions.
\end{abstract}

Keywords Climate change $\cdot$ Pamir Mountains $\cdot$ Local knowledge $\cdot$ Perception $\cdot$ Climate data Statistical downscaling

Isabell Haag

isabell.haag@uni-bayreuth.de

Extended author information available on the last page of the article 


\section{Introduction}

Understanding the dimensions and effects of climate change in extra-alpine mountain regions remains a research challenge because of limited availability of instrumental climate data. However, this challenge has to be overcome as subsistence-based communities, who have contributed little to the causes of anthropogenic climate change, are the ones facing its harshest impacts (Kohler et al. 2010). Changes in mean climate and enhanced climate variability affect rural livelihoods, food systems, and infrastructure (López et al. 2017; Manandhar et al. 2018). Whereas the accuracy of instrumental climate data is often lacking in mountain environments, agropastoral communities, whose lifestyle is inherently connected to their habitat, possess deep-rooted knowledge of local weather and climate. This knowledge is usually derived from close observations of their biophysical surrounding (Boillat and Berkes 2013; Byg and Salick 2009; Chaudhary and Bawa 2011). Passed down through generations this knowledge can be found incorporated into daily practices of agriculture, herding, medicine, or other sociocultural events (Kalanda-Joshua et al. 2011; Kassam et al. 2018; King et al. 2008). Whereas both knowledge systems entail their individual uncertainties and biases, integrating local knowledge with available instrumental data can broaden the scope of available climate information at the village scale, which can provide valuable information for climate adaptation or impacts studies (Ford et al. 2016; García-Del-Amo et al. 2020).

Only few studies have adopted an integrated assessment of instrumental climate data and community observations in order to investigate in local scale climate processes. Studies can be found in South America (Fernández-Llamazares et al. 2017; Kieslinger et al. 2019; López et al. 2017), the Arctic (Cuerrier et al. 2015; Gearheard et al. 2010; Rapinski et al. 2018; Williams et al. 2018), Africa (Ayanlade et al. 2017; Kalanda-Joshua et al. 2011; Meze-Hausken 2004; Simelton et al. 2013), or the Himalaya (Gentle and Maraseni 2012; Klein et al. 2014). While transdisciplinary approaches are conceptually and methodologically challenging, they appeared to be particularly promising in data-deficient environments, where local communities pursue subsistence-based livelihoods and closely anticipate changes in climate and environment over a sustain period. Studies showed, that community perceptions of climate change often coincided with measured meteorological trends (López et al. 2017; Rapinski et al. 2018). Beside concordances, studies also identified different trend observations between the two data sources (e.g. Abu et al. 2019; Fernández-Llamazares et al. 2017). To synthesise information across both knowledge systems, their individual limitations have to be acknowledged, such as uncertainties in the measurements and analysis of instrumental data records or the potential variability in the substance and quality of personal perceptions within a community (Alexander et al. 2011). Despite methodological challenges, studies concluded that the integration of instrumental data with peoples' observation can strengthen the understanding of local climate change in remote areas around the globe, and introduce new perspectives to the existing field of climate change research. Co-generated knowledge can ensure a sustainable development of local communities, strengthen their resilience towards climate change and support effective adaptation strategies and policies (Kieslinger et al. 2019; Kalanda-Joshua et al. 2011).

As previous studies have shown the potential of taking a multiple evidence approach, this study is the first one integrating community observations with instrumental climate data in the Pamir Mountains of Tajikistan. The Pamirs constitute a suitable research area for such an integrative study design as local trends and impacts of temperature and precipitation change remain mostly unknown due to a low network of meteorological stations (Xenarios et al. 2019). At the same time, local communities were shown to possess detailed knowledge of their 
ecological and climatological environment, which they incorporate in daily agricultural practices and store in the form of complex ecological calendars (Kassam et al. 2011; Kassam et al. 2018). In order to generate new information about local climate trends in the Pamirs, which can be crucial for climate adaptation or impacts studies, the aims of this study are threefold:

1. Generate and analyse high-resolution climate time series that match the scale of community observations.

2. Valorise community perceptions of local trends in temperature, precipitation, and snow.

3. Synthesise information about local trends in temperature, rain, and snow by integrating community perceptions and instrumental climate data.

A number of data sets and methods were used to gain information about relevant climate variables, including trends in temperature, precipitation, and snow cover. To receive highresolution temperature estimates at the village-scale, we downscaled ERA5 temperature data using a lapse rate based approached. Lapse-rate downscaling can enhance the spatial accuracy of gridded data sets above data-scarce regions, as it works independently to meteorological ground stations (Gao et al., 2012; Gao et al., 2017). Temporal variations in snow cover were investigated using daily data from the MODIS snow product MOD10A1 (Hall and Riggs 2016). In addition to measured data products, community perceptions were gathered using semi-structured interviews and community workshops. Our research approach is built on a respectful research relationship between scientists and local communities and can be applied in other data-deficient regions around the word to foster more transdisciplinary climate research.

\section{Study sites \& research relationship}

This study has been conducted in the Pamir Mountains of Tajikistan, in the villages of Roshorv and Savnob (Fig. 1). The Pamir Mountains cover the regional districts of the Tajik Gorno-Badakhshan Autonomous Oblast (GBAO), the Afghan province of Badakhshan, the Western part of the Chinese province of Xinjiang, and the southernmost part of the Kyrgyz Osh region. The research sites are located in the western part of the Tajik Pamirs, characterized by a semi-arid climate with precipitation peaks in winter and spring (Aizen et al. 2001; Finaev et al. 2016). The regions supply of water for drinking, irrigation, and energy production depends almost entirely on glacier-fed rivers, making water a valuable and limited resource (Aizen et al. 2007). The village of Roshorv is located on a spacious plateau on an altitude of 3139 meter above sea level (masl). Savnob, which is constrained by steep mountain hills and a gorge, is located on an altitude of 2692 masl. In both villages, people traditionally live as subsistence-based farmers and herders with little monetary income. Because Savnob and Roshorv are located in deep mountain valleys pervaded with a fragile network of roads and treks, inclement weather conditions or mass movements can lead to isolation, cutting them off from key supply routes. Therefore, an autonomous food supply is very important to ensure food security throughout the year. Both communities belong to the ethnicities of the "Bartangi", speaking one of the Pamir languages "Shugni" (Kassam et al. 2011).

A research relationship with both communities was firstly established by the second author in the year 2006. Based on this relationship an action research initiative was launched in 2015, focusing on the revitalization of ecological calendars in Savnob and Roshorv to enhance the 

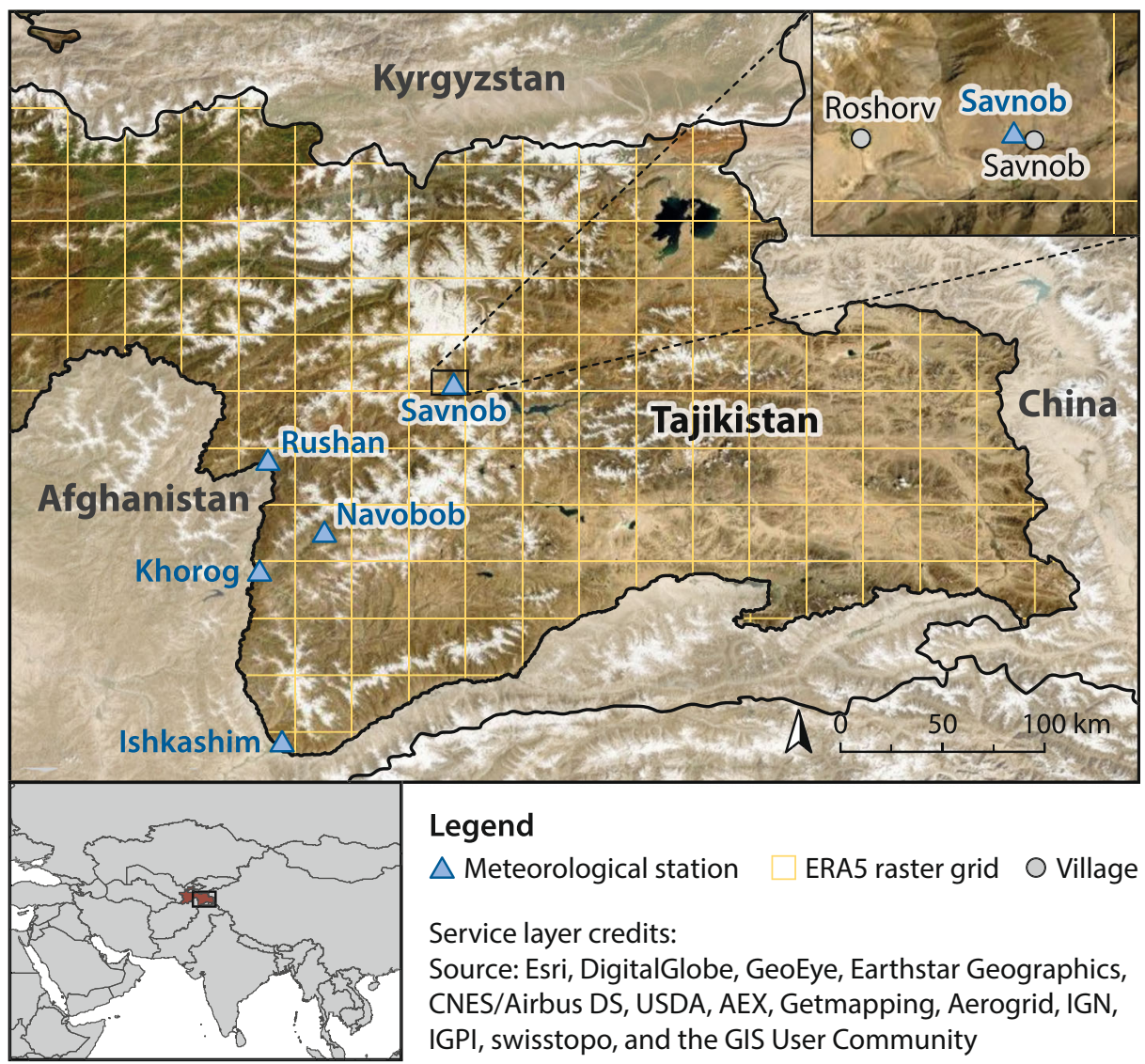

$\triangle$ Meteorological station

ERA5 raster grid

Village

Service layer credits:

Source: Esri, DigitalGlobe, GeoEye, Earthstar Geographics, CNES/Airbus DS, USDA, AEX, Getmapping, Aerogrid, IGN, IGPI, swisstopo, and the GIS User Community

Fig. 1 Map of the study region showing the Pamir Mountains of Tajikistan and the location of the research villages Savnob and Roshorv, and the meteorological stations applied in this study.

adaptive capacity of the communities to the impacts of climate change (Kassam et al. 2018). Within this research initiative, data for this study was acquired in two 2-week field sessions in summer 2018 and 2019. The integration with the overhead project on ecological calendars considerably contributed to the effectiveness of this study, because (1) a research relationship with the communities was already established since the year 2006, (2) ongoing research on ecological calendars provided important a-priori information regarding the human ecological and environmental situation of the two communities (information on ecological calendars can be found in Kassam et al. 2018), and (3) jointresearch activities, such as two community workshops in 2018, were used to inform both research initiatives simultaneously and to show interlinkages. An important focus of both studies was to create an effective research relationship and to engage local knowledge holders in the research process (Woodward, 2010). Before the start of our work we informed the religious leader and the secular head of the village organization about our intentions and asked for their participation, which they always generously consented to. All interactions have been supported by a local community researcher in the native language of the communities. 


\section{Material and methods}

To assess climate change impacts at the level of the villages, we used a number of datasets including reanalysis data, satellite data, and community observations. A graphical outline of the applied research tasks is provided in the online resources of this manuscript. Throughout the whole research design and implementation, we valued each data type as equally insightful and each mutually guided the research process.

\subsection{Downscaling and temperature trend analysis}

Monthly temperature trends ranging from 1979 to 2018 have been derived by applying an elevation correction approach to the gridded temperature product ERA5 (Copernicus Climate Change Service 2017). ERA5 is provided by the European Centre for Medium Range Weather Forecast (ECMWF) and delivers various atmospheric, land-surface and sea-state parameters at different pressure levels utilizing both past observations and models. More information on the assimilation scheme and performance of ERA5 can be found in Hersbach et al. (2018). To capture the small-scale variability of near-surface temperature in complex terrain, we applied an elevation correction to the original ERA5 dataset to enhance its spatial resolution from 31 kilometres to point-scale. To apply the proposed elevation correction approach of ERA5, the following variables are needed: monthly means of the 2-meter temperature $(2 \mathrm{mT})$, surface pressure and orography on a single level, and temperature and geopotential at the 400,450 , $500,550,600,650,700,750,775,800,825,850 \mathrm{hPa}$ levels.

To evaluate the performance of the newly generated elevation corrected ERA5 dataset over the Pamirs we used temperature data of existing meteorological stations from different altitudes across the Pamirs. For this purpose, eleven meteorological station records have been acquired from the State Administration for Hydrometeorology of the Republic of Tajikistan (SAHRT). Station records cover the period from 1995 to 2012 at a monthly frequency (State Administration for Hydrometeorology of the Republic of Tajikistan 2013). Following the guidelines from the World Meteorological Organisation, stations with a minimum data coverage of $80 \%$ and less than $5 \%$ missing values were maintained (Zahumenský 2004). After the quality check, five stations remained for validation (Fig. 1). More information on the location and altitude of the stations can be found in Online Resource 1. Apart from SHART stations, two automated weather stations were installed in Savnob and Roshorv between 2016 and 2019 by the research team conducting this study. This station data was used to identify the most suitable combination of pressure levels to calculate monthly lapse rates for the research locations.

The elevation correction of ERA5 $2 \mathrm{mT}$ was done after the proposed method of Gao et al. (2017), using ERA5 internal vertical temperature gradients. Those lapse rates $(\Gamma)$ define the relationship between temperature and elevation and can be used to adjust the original ERA5 grid height to a target elevation. Lapse rates are determined monthly to account for atmospheric variations and are based on the temperature and geopotential height at different preselected pressure levels (Equation 1).

$$
\Gamma=\frac{\left(T_{h P a \_}-T_{h P a \_}\right)}{\left(G p H_{h P a \_A}-G p H_{h P a \_B}\right)}
$$

, where $T_{h P a}{ }_{A}$ and $T_{h P a}{ }_{B}$ represent the temperature at the highest and lowest pressure level, respectively. And $\mathrm{GpH}_{\mathrm{hPa}{ }_{-}{ }_{A}}$ and $\mathrm{GpH}_{\mathrm{hPa}{ }_{-}{ }_{B}}$ represent the geopotential height of the respective pressure levels. 
To account for varying atmospheric conditions, lapse rates based on four pressure level combinations were calculated (c. f. Gao et al., 2012): (1) $\Gamma_{A}$ is based on the maximum and minimum elevation, (2) $\Gamma_{B}$ is based on the ERA5 grid height and minimum elevation, (3) $\Gamma_{C}$ is based on ERA5 grid height and the height of the pressure level below the target elevation, and (4) $\Gamma_{D}$ is based on the height of the two pressure levels below and above the weather station. Whereas $\Gamma_{A}$ captures the largest elevation difference, $\Gamma_{B}$ accommodates higher elevation conditions, and $\Gamma_{D, C}$ accounts for local circulation patterns. Pressure levels closest to the respective reference height were applied. In case of a temporal variability of pressure levels found to be closest to one reference height, the level with the highest distance to its counterpart was chosen. To correct ERA5 $2 \mathrm{mT}$, equation 2 was used, with varying $\Gamma$.

$$
T_{\text {cor }}=T_{E R A \_2 m}+\Gamma^{*} \Delta h
$$

,where $T_{E R A_{-} 2 m}$ is defined by the $2 \mathrm{mT}$ of ERA5 and $h$ the difference between $\mathrm{GpH}_{\mathrm{PPa} a_{-} A}$ and $\mathrm{GpH}_{\mathrm{hPa} \mathrm{B}_{\mathrm{B}} \text {. }}$

To evaluate the elevation correction method, both original ERA5 and corrected ERA5 must be compared to the validation stations. Therefore, four accuracy measures were calculated, and model data was tested against the station inside the corresponding raster cell. As suitable accuracy measures, the coefficient of determination $\left(\mathrm{R}^{2}\right)$, the root mean squared error (RMSE), the mean absolute error (MAE), and BIAS were used. Information on the formula to calculate those accuracy measures can be found in Online Resource 1.

To test for a statistically significant performance difference between the original and corrected data sets, the paired two sample Wilcoxon Rank-Sum Test using the absolute differences between the meteorological station data and the corrected dataset was applied. As a last step, the linear trend analysis using the elevation corrected ERA5 dataset, was conducted. The trend magnitude and trend significance were derived using the Sen's slope estimator and the Mann Kendall test, respectively (Kendall 1975; Mann 1945; Sen 1968; Theil 1950).

\subsection{Snow trend analysis}

To detect temporal changes in local snow patterns, the snow cover product MOD10A1 based on the images of the moderate resolution imaging spectroradiometer (MODIS) on board the Terra Satellite was chosen (Hall et al. 2016). MOD10A1 provided daily images of the snow signal in form of the Normalized Difference Snow Index (NDSI) starting in spring 2000 to present, with a spatial resolution of nominal 500 meters. In this study all available MOD10A1 images from 2001 to December 2018 have been acquired via the National Snow and Ice Data Centre. More information on data structure, snow algorithm, and uncertainties can be found in Riggs et al. (2016). Whereas previous studies have confirmed the suitability of MODIS snow cover products for snow detection in mountainous terrain (e.g. Gascoin et al. 2015; Jain et al. 2008) and its high accuracy over Central Asia (Gafurov et al. 2013), uncertainties in snow cover values exists due to the influence of clouds, different snow characteristics, or illumination conditions (Brubaker et al. 2005; Crawford 2015). Since cloud covered pixels are the main limitation of snow cover products such as MOD10A1, several gap-filling approaches exist to derive cloud-free images (c.f. Hall et al. 2019). In this study a temporal gap filling procedure was applied using a simple linear interpolation of the NDSI values. Gaps at the very beginning or end of a time series without preceding or subsequent values, were filled by using the closest available value. Whereas more complex cloud removal approaches exist (e.g. Gafurov and 
Bárdossy 2009), a simple temporal gap filling can already provide good results and enhance the accuracy of snow cover estimates at a given day (Hall et al. 2019).

To detect temporal changes in snow cover we used the NDSI time series for: (1) the grid cells, in which the villages are located; and (2) the grid cells intersecting a one-kilometre buffer zone around the villages. Considering the local topography, the buffer zone accounts for those areas surrounding the villages, which are visible to the communities and influence their perception of snow. To identify changes in the timing of snow onset, snow offset and changes in the length of the snow period, we defined the full snow season (FSS) after Choi et al. (2010).

$$
F S S=(52 \text { weeks }- \text { FSS onset week })+\text { FSS offset week }
$$

, where FSS onset week is defined as the first week after summer, where the number of days with a snow cover $>50 \%$ prevail. FSS offset week is defined as the first week of the year, where the number of weekdays with a snow cover $<50 \%$ prevail.

For the snow trend analysis, the grid cells of the villages and the grid cells located within the buffer zone, were taken into consideration. The trend magnitude was derived using the Sen's slope estimator and the trend significance using the Mann-Kendall test. All processing steps regarding temperature and snow analysis were done using the R Software environment (R Core Team 2018).

\subsection{Community observations}

\subsubsection{Community Workshops 2017 and 2018}

A first round of community workshops were held in 2017 at the $20^{\text {th }}$ of June in Savnob (20 participants) and at the $27^{\text {th }}$ of June in Roshorv (18 participants) to establish a relationship between community members and scientists. Because of cultural differences and the difficult accessibility of the research villages, scientists needed to make themselves familiar with the sociocultural and biophysical situation of the communities in order to tailor the interview questions to the community livelihoods. The workshops were organised by synchronous research activities on traditional ecological calendars, where scientists of this publication were also involved. In the workshops, communities created seasonal rounds which provided insights into local livelihoods, ecological events, and environmental and climatological conditions (Kassam et al. 2018). The workshops of 2017 lasted for three hours.

In 2018, a second round of workshops was held ( $2^{\text {nd }}$ of July in Savnob with 23 participants, $6^{\text {th }}$ of July in Roshorv with 19 participants) to provide space for all community members to participate in the research and to identify knowledgeable community members to be questioned in the individual interviews. Participants were questioned about seasonal changes in temperature, precipitation, and snow. Questions were identical to the interview questions of 2018 and can be found in Online Resource 1. Workshops were further used to share scientific information about regional climate trends with the community members to initiate a two-way learning process (Haag et al., 2019). The workshops were conducted in the homes of village leaders and were always started with a shared meal. The workshops of 2019 lasted for two hours.

\subsubsection{Structured interviews 2018 and 2019}

Structured interviews were conducted in June 2018 and June 2019 to assess individual observations of local climate change. The aim of the interviews was to extract information 
about seasonal trends in temperature, precipitation, and snow cover. In 2018, only five interviews were conducted in each village with key informants, who were identified in the community workshop. Time constraints prevented a higher number of interviews. Despite the small number, interviews were important to test the structure and wording of the interview questions as cultural and linguistic differences between scientists and informants existed. In 2019, 20 more interviews were conducted in each village. New interview participants were identified with the help of the village leader and selected according to their age, gender, and ecological profession. In order to get a historical sense of weather changes, most participants were farmers and herders above the age of 50 and must have spent most of their life in the village. Interviews took place at the interviewees' home or farm. As some traditional communities can have their own seasons, informants were asked to provide a short definition of their seasonal understanding. In 2019, interviews were used to further investigate in the temporal component of climate trends and their potential indicators. Last one was investigated by asking e.g. "How do you know autumn is warming?". To help participants anticipate long-term changes in climate rather than short-term weather fluctuations, we used a set of historically time markers, whose importance for the communities was identified with the help of our local community researcher. In 2018, time markers referred to exact years, such as "2015 - the year of the earthquake" or "1990 - the collapse of the Soviet Union". In 2019, we changed the structure of the time markers from single years to periods of time to prevent interviewees to primarily refer their answers to one year or season. The full set of questions for the interviews in 2018 and 2019 and the respective time markers can be found in Online Resource 1. Before each interview, informed consent was sought to record and to use the interview for research purposes. In no instance did a community member refuse to participate.

To analyse community observations on climate trends and to identify shared patterns of knowledge, we calculated a consensus index based on Rapinski et al. (2018). Transforming qualitative data into semi-quantitative variables helps to reduce the complexity of the information and to identify general trends using the level of agreement within the community. Similar to the concept of a cultural consensus analysis, the consensus index assumes a relationship between the level of agreement within the group of respondents and the accuracy of the proclaimed observation (Romney et al. 1986). In this study, we calculated a consensus index $(d F C)$ to quantify the magnitude and direction of change of a specific observation following the approach by Rapinski et al. (2018).

$$
d F C=\sum w f / F
$$

, where $f$ is the number of observations and $F$ the total number of interviews. $w$ is the code attributed to the observation, regarding its direction. Whereas increasing trends (e.g. rising temperatures, increasing precipitation, later onset/offset of snow) received the code 1, decreasing trends received the code -1 . If no trend direction was identified, the observation was coded with 0 . An overview of the observations and the corresponding codes can be found in Online Resource 1.

The obtained $d F C$ index ranks between -1 and 1, indicating the direction of change and its level of agreement within the community. If $d F C$ equals 1 or -1 , a complete agreement can be noted. If the index is close to 0 , no consent could be achieved. The results of the consent analysis are based on the 50 interviews undertaken by the first author in 2018 and 2019. 


\section{Results}

\subsection{Temperature trends}

To derive village scale temperature trends, we first downscaled ERA5 temperature data and validated the suitability of this approach before conducting the trend analysis. The performance of the original ERA5 data and the two best correction methods are summarized in table 1, which can be found in Online Resource 1 of this manuscript. Original ERA5 shows a good temporal correlation with the station data with $\mathrm{R}^{2}$ values between 0.88 and 0.95 . Whereas BIAS ranges between $-12.32{ }^{\circ} \mathrm{C}$ and $-16.34{ }^{\circ} \mathrm{C}$, which indicates a general cold bias of the original ERA5 dataset, RMSE and MAE show an average error across all stations of $14.54{ }^{\circ} \mathrm{C}$ and $14.26{ }^{\circ} \mathrm{C}$ per month, respectively. Regarding the magnitude of the error measurements, a relation between the error size and the altitude difference between model and station data can be observed. Rushan, with the greatest altitude difference of 1544 meters, shows the highest model errors. Navobob, with the smallest altitude difference of 1252 meters, depicts the lowest model errors across all stations. Savnob deviates from that trend, as its elevation difference is low, but model errors exceed all other stations. Given that four correction methods have been applied initially, only performance measures of method $\Gamma_{\mathrm{D}}$ and $\Gamma_{\mathrm{C}}$ are presented in table 1 , since they delivered the best results. The presented methods show a reduction in the RMSE between $52 \%$ to $62 \%$ and a significant decrease in the MAE between $55 \%$ to $65 \%$ compared to the error measurements of the original ERA5 data. Furthermore, the initial cold bias of ERA5 was reduced by $52 \%$ to $64 \%$. Although the correction methods lead to a reduction in the RMSE, MAE, and BIAS, no improvement in the temporal correlation could be achieved. Regarding the relation between error magnitude and difference in elevation, no pattern could be discerned anymore after the elevation correction was applied. Whereas the correction methods substantially improved the model performance of ERA5, unpredictable errors remained (results not shown here). Those remaining errors show a seasonal distribution, being lowest in winter.

Using the elevation corrected ERA5 dataset for the temperature trend analysis we identified a statistically significant increase in summer temperatures in both villages. Summer temperatures increased by $0.32{ }^{\circ} \mathrm{C}$ per decade and $0.38{ }^{\circ} \mathrm{C}$ per decade in Savnob and Roshorv, respectively (Table 1). The second highest trend magnitudes according to ERA5, were detected in autumn for both villages. However, those trends are not significant on a statistical basis which also applies for the two lowest trend magnitudes in spring and winter.

Table 1 Annual and seasonal temperature trends per decade $\left({ }^{\circ} \mathrm{C}\right)$ for the villages Savnob and Roshorv (19792018) using the elevation corrected ERA5 temperature data. Asterisk indicates the significance level $(p<0.05)$.

\begin{tabular}{lll}
\hline & Savnob & Roshorv \\
\hline Annual & $0.15[-0.03$ to 0.32$]$ & $0.17[-0.03$ to 0.37$]$ \\
Spring & $0.09[-0.14$ to 0.33$]$ & $0.07[-0.15$ to 0.3$]$ \\
Summer & $0.32^{*}[0.03$ to 0.61$]$ & $0.38^{*}[0.04$ to 0.76$]$ \\
Autumn & $0.22[-0.17$ to 0.61$]$ & $0.27[-0.2$ to 0.69$]$ \\
Winter & $0.11[-0.25$ to 0.49$]$ & $0.09[-0.32$ to 0.5$]$ \\
\hline
\end{tabular}




\subsection{Snow trends}

Using the MOD10A1 snow cover product revealed temporal changes in the snow cover extent between 2001 and 2018 in the villages of Savnob and Roshorv. The results showed an increasing trend in the timing of snow onset and a decreasing trend in the timing of snow offset, combined leading to a shortening of the snow season (Fig. 2). Whereas snow tends to arrive later and melt earlier, those observations are

\section{a Snow onset}

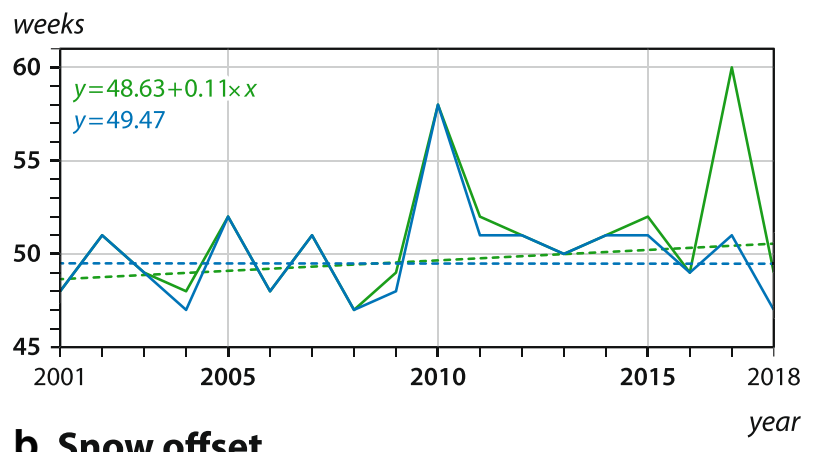

\section{b Snow offset}

weeks

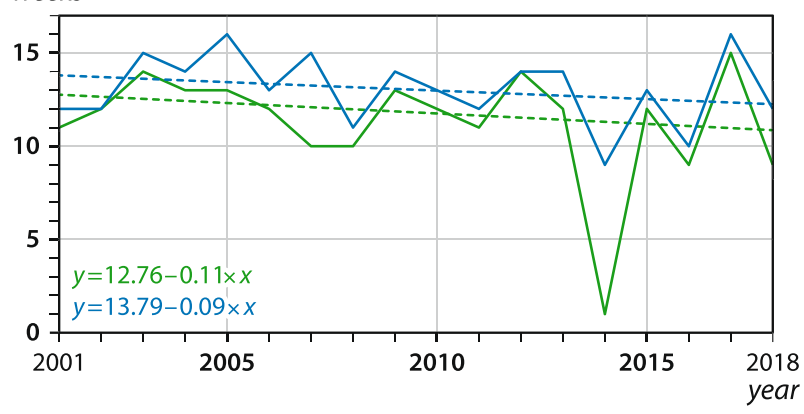

\section{Length of snow period}

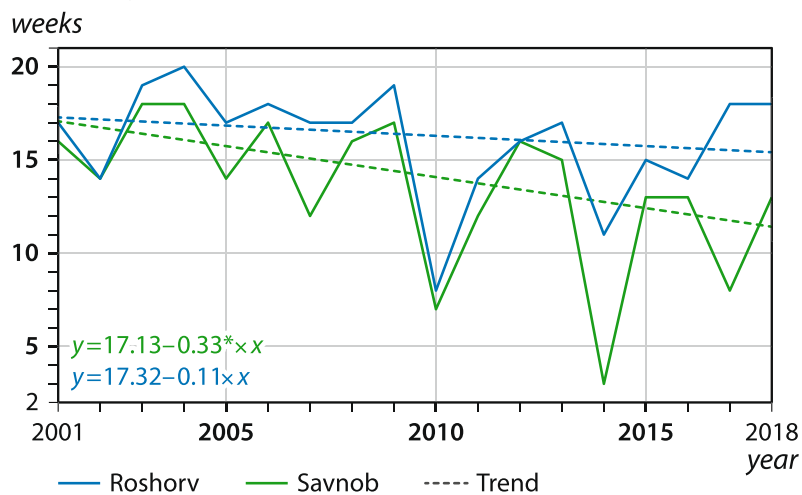

Fig. 2 Changes in the timing of snow onset, snow offset and in the duration of the snow period in weeks for the villages Savnob and Roshorv. Data was derived from the satellite-based snow cover product MOD10A1. Asterisk indicates the significance level $(\mathrm{p}<0.05)$. 
not statistically significant. The only significant change detected in terms of snow cover extent, was the decreasing length of the snow period in Savnob (Fig. 2C). The period of snow in Savnob shortened by 5.4 weeks between 2001 and 2018.

\subsection{Community observations and indicators}

As community observations can be multidimensional and complex, a consensus index enabled to identify shared patterns of observations (Fig. 3). In this study, we consider a dFC index between 0.3 and 0.65 as moderate consent, between 0.65 and 0.8 as strong consent, and above 0.8 as very strong consent. This stratification follows the scheme outlined in Rapinski et al. (2018), with an additional class to differentiate high levels of consent. Observations reaching a consent under 0.3 are not further considered in this study. In Roshorv, the community members reached very strong consent regarding decreasing levels of snow (dFC of -0.82). Moderate agreement was reached in terms of increasing autumn and winter temperatures, decreasing levels of rain, and a delay in the timing of snow onset. In Savnob, moderate consent was reached for decreasing levels of snow and rain ( $\mathrm{dFC}$ of -0.5$)$ and increasing temperatures in winter ( $\mathrm{dFC}$ of 0.5$)$.

Whereas changes in weather and climate are often not directly visible, community members explain their perceptions by ecological or sociocultural indicators and impacts. In Savnob and Roshorv, indicators were identified in regard to agriculture, infrastructure, natural environment and daily routines. Indicators mentioned three or more times in the interviews are listed in Fig. 4. Indicators reported in both villages include an earlier time of harvest, earlier start of fieldwork, decreasing demand for heating resources, earlier melting of snow, and a more comfortable feeling because of warmer temperatures.

"In the past, we harvested later. Sometimes it took us until October. Now, we finish our harvest in September. Wheat, barley, and beans have ripened at that time.” (R13, 2019)

\section{Community consensus}

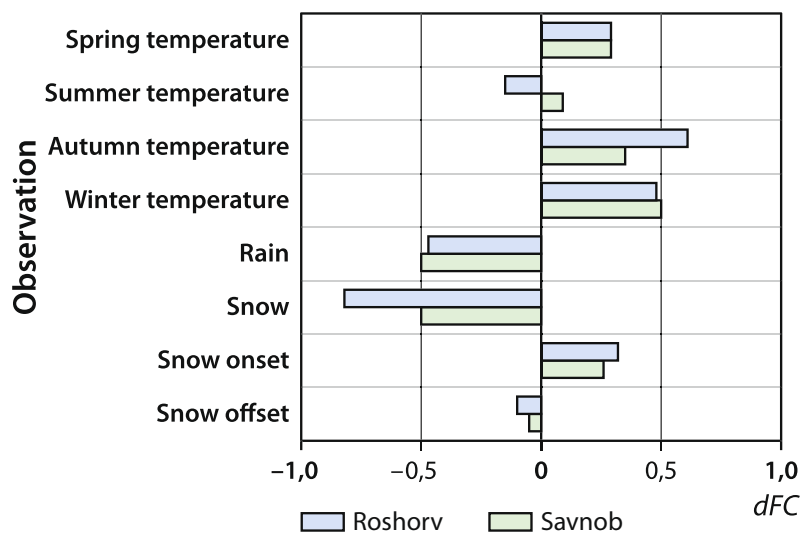

Fig. 3 Observations of meteorological changes, reported by the villagers of Savnob and Roshorv. The $\mathrm{dFC}$ index shows the direction of change and its consent among the community members. The closer the index to $-1 / 1$, the higher the agreement. Positive index values indicate an increase/delay, and negative values a decrease/earlier start. The consensus index is based on 50 interviews, which were conducted in Savnob and Roshorv in 2018 and 2019. 


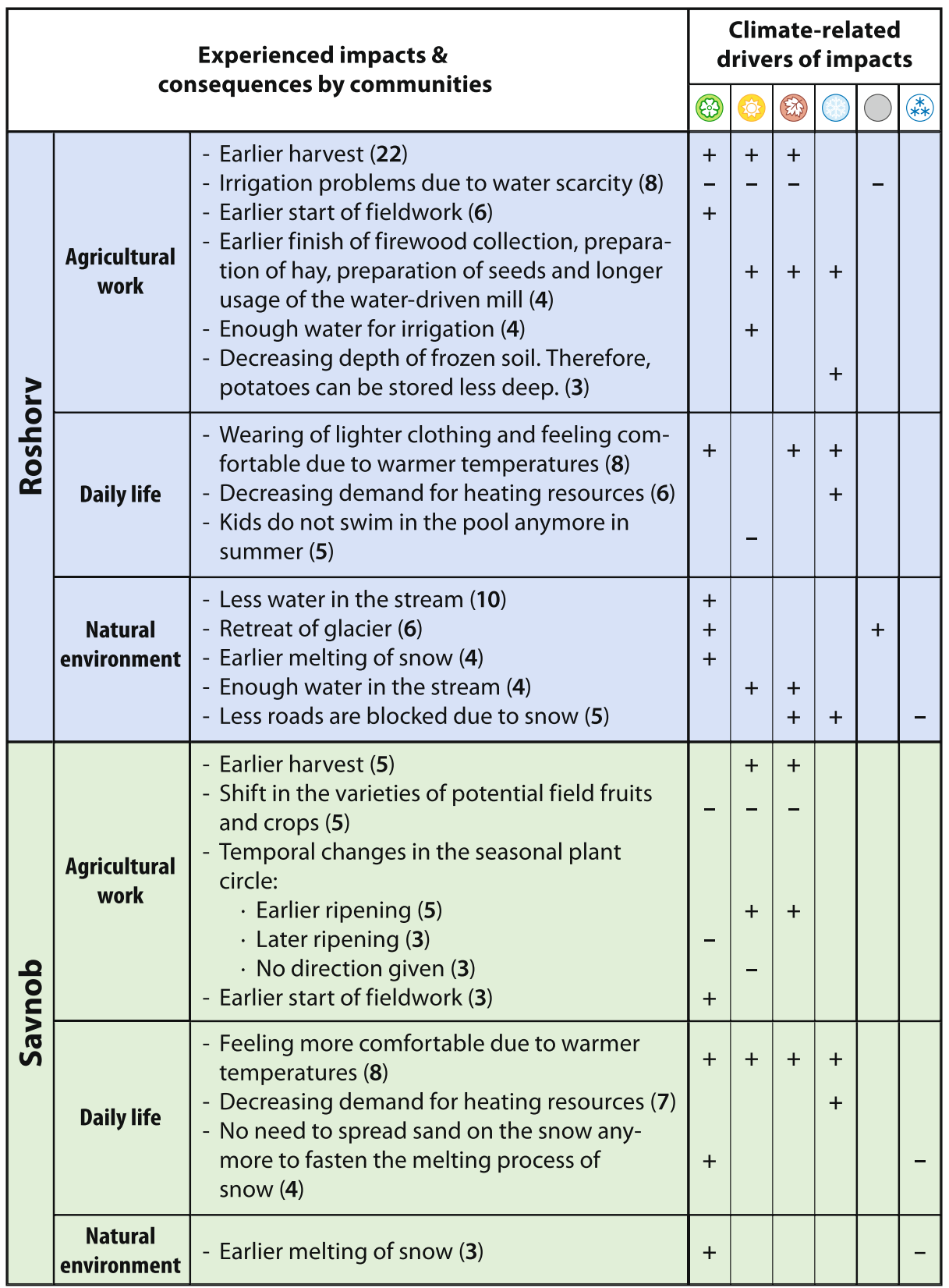

Temperature in:

(83) Spring Summer Autumn Winter $\bigcirc$ no season specified
**) Snow level
+ Increase - Decrease
(x) Number of times mentioned 
Fig. 4 Impacts and indicators of climate change reported by the community members of Savnob and Roshorv in the interviews of 2019 Numbers in parenthesis indicate how many times an indicator was mentioned within a community. Climate-induced drivers (i.e. seasonal changes in temperature and snow) have been identified by the community members in relation to their reported indicator. For example, 22 respondents in Roshorv reported that harvest is occurring at an earlier time of the year. Possible drivers for that change have been identified as increasing temperatures in spring, summer, and autumn.

In Roshorv, conflicting observations were made about the availability of water, which is provided to the village by a glacier-fed stream. According to eight respondents, there is less water in the stream resulting in insufficient water availability for irrigation. However, four other respondents stated a sufficient water supply for irrigation. Regardless its effects on agriculture and irrigation, community members independently reported less water in the stream and a decrease in the size of the glacier above the village. Concerning the communities' infrastructure, people in Roshorv explained that their roads and paths are less blocked by snow in winter, due to shrinking levels of snow.

"Since the 1980s snow is becoming less and less. Before the 1990s we had to clean the roads to Gudara and Savnob every winter. Now, cars can drive there without having to clean the road first." (R17, 2019)

Decreasing amounts of snow have also been reported in the villages of Savnob. People remember that in earlier times they spread sand on the snow to hasten the melting process.

Although, nature-based communities have learnt over generations to anticipate changes in weather and climate, community members frequently mentioned enhanced variability in the weather. Annual fluctuations in the timing of plant blossoming and field fruit maturity have been mentioned as indicators for increased weather variability. Additionally, three people directly reported that the weather is getting more variable and the seasons more unpredictable. For subsistence-based farmers, higher variability in the weather can have severe impacts on their harvest and unpredictability of seasons results in anxiety (Kassam et al., 2011). At no time, people associated anthropogenic climate change as a potential cause behind their experienced impacts. Instead, people argued that their perception of changes in weather and climate might rather be influenced by their age, health, ecological profession, beliefs, changes in machinery, or availability of heating resources.

"We feel that it is getting warmer. An explanation is that in the past we had community farms (Kolkhoz) and state farms (Sovkhoz) and not everyone had to work on the fields. Maybe after this period we started feeling the heat because more people became farmers and had to work on the fields again. However, people started to become farmers in 1991 [after collapse of the Soviet Union and during the civil war] and we started to feel that it is getting warmer around 1995/1998." (R5, 2019)

\subsection{Cogeneration of knowledge using community observations and instrumental data}

In order to derive more detailed information about local climate trends in Savnob and Roshorv, instrumental data records and community observations were integrated and areas of similarity and difference identified. No concordances could be identified in terms of temperature trends. Whereas a significant increase in summer temperatures was shown by the downscaled ERA5 records, community members of Roshorv reached strong consent on warming temperatures in 
autumn and winter. In Savnob, strong consent was only reached on warming temperatures in winter. ERA5 also showed a warming trend for autumn and winter but not on a statistically significant level. In terms of snow, community observations and instrumental data related partly to different characteristics of snow. Whereas community members anticipated the amount of snow, the applied remote sensing data provided long-term measurements of snow cover extent. Community members of both villages indicated decreasing levels of snow and the analysis of satellite images revealed a shortening of the snow season in Savnob. Evidence for a shorter time period was also derived from the community observations of Roshorv. Community members identified a delay in the timing of snow onset. In terms of rain, only community observations provided information about possible trends directions. With a moderate level of agreement, communities indicated a decrease in rain. No information could be achieved by using instrumental climate data.

\section{Discussion}

\subsection{Instrumental climate data}

In extra-alpine mountain environments, gridded data products can show high uncertainties in predicting local-scale climate conditions because of their low grid resolution and the limited availability of in-situ measurements (Hu et al. 2016). In the Pamirs, those data restrictions lead to prevailing uncertainties about local-scale climate trends (Unger-Shayesteh et al. 2013). One objective of this study is to generate high-resolution climate data for the villages Savnob and Roshorv to investigate in local trends of temperature and snow. In terms of temperature, local time series were generated by downscaling ERA5 data, using a lapse rate based approach (c.f. Gao et al. 2017). Our downscaling resulted in a maximum reduction of the RMSE and MAE of $62 \%$ and $65 \%$ compared to the uncorrected dataset over the Pamir, respectively. The magnitude of this error reduction is in accordance with previous studies carried out by Gao et al. (2012) and Gao et al. (2017) using the precursor dataset of ERA5, ERA-Interim, over the Tibetan plateau. Although, the proposed method shows a good model performance over the Pamirs, the evaluation is limited to the regional scale due to the low number of available validation stations. However, this situation is characteristic for large areas worldwide (Zandler et al. 2019). In addition, unpredictable residuals with a seasonal pattern remained in the corrected ERA5 data. Drawing on the conclusion made in Gerlitz et al. (2014), those seasonal patterns could be related to unresolved incoming solar radiation or meso- to local-scale circulation patterns. Further possible factors controlling near-surface temperature, which remain unresolved in the proposed elevation correction approach include latent heat transfer, topographic effects, observational errors, largescale biases, or internal model background errors (Gao et al. 2017; Gerlitz et al. 2014). A trend analysis of the downscaled ERA5 data finally revealed an increase in temperature between 1979 to 2018 throughout all seasons in Savnob and Roshorv. However, only summer warming was statistically significant with $0.32{ }^{\circ} \mathrm{C}$ per decade and $0.38{ }^{\circ} \mathrm{C}$ per decade, respectively (Table 1). Regional studies on temperature change in Central Asia also agreed on a general warming trend but with varying trend magnitudes among the seasons (Chen et al. 2009; Finaev et al. 2016; Haag et al. 2019; Hu et al. 2014). Our results show, that uncertainties of local climate change, arising from counterintuitive findings of regional temperature studies, can be substantially reduced by generating village scale temperature trends using the elevation-correction approach based on ERA5 internal vertical lapse rates after Gao et al. (2017). Despite remaining uncertainties, lapse 
rate downscaling can provide more accurate temperature estimates for Savnob and Roshorv than received from the original ERA5 data.

Trends in local snow patterns were directly derived from the snow cover product MOD10A1 with a pixel resolution of 500 meters. Results showed a statistically significant shortening of the snow period in Savnob. Results on snow variations in Roshorv and temporal variations in the timing of snow onset and snow offset in both villages were not statistically significant. Other regional studies over the Pamirs also indicated a decrease in snow cover as well as a shift towards earlier snow melt in spring (Dietz et al. 2014; Li et al. 2018). Different study results or missing statistical significance can be caused by the fact that patchy snow cover in the subpixel scale might not be detected by MOD10A1 (Hall and Riggs 2007). Furthermore, the general availability and accuracy of optical remote sensing images can be constrained by cloud cover, solar illumination, and sensor viewing geometry and thus influence the estimation of snow cover in mountainous terrain (Crawford 2015). Whereas MOD10A1 can provide reasonable information about local variations in snow cover, community members of Savnob and Roshorv showed a higher anticipation of snow amounts rather than snow extent. It was not possible to assess the depth of snow using instrumental data, as operational observations of snow depth still face technical limitations in their spatial, temporal, and vertical resolution in mountain environments (Lievens et al. 2019).

\subsection{Community observations}

Traditional communities around the world were shown to possess detailed knowledge of weather and climate, which is based on daily practices and observations (e.g. Green et al. 2010; Ifejika Speranza et al. 2010; Ingty 2017). In the Pamirs, Kassam et al. (2018) already reported a close anticipation of ecological and environmental processes by the community members of Savnob and Roshorv. Building on those results, this study aims to investigate in community perceptions of local climate trends. Results show, that both communities shared a high consent in regard to decreasing trends in rain and snow, and increasing temperatures in winter. Community members of Roshorv further identified a warming trend in autumn and a delay in snow onset (Fig. 3). According to previous studies, community observations are (i) biased towards changes which are directly visible or affect local livelihoods (c.f. Rapinski et al. 2018; Riseth et al. 2011), and (ii) vary in their quality and substance between community members (Fernández-Llamazares et al., 2017). First one applies to the high community consent in Savnob and Roshorv in regard to decreasing levels of snow. Whereas snow is directly visible to the people, it also dictates the timing of herding activities and controls the hydrological cycle in the villages. Furthermore, communities face isolation when there is too much snow, impeding any contact with neighbouring villages and disabling any kind of external provisioning. Therefore, people pay close attention to changes in snow, which enhances the reliability of such observations. Similar to the communities of Savnob and Roshorv, resource-based communities were shown to anticipate changes in temperature by using a set of ecological or sociocultural indicators, such as changes in the timing of agricultural activities, agricultural yields, livestock, infrastructure, or health (c.f. Ayanlade et al. 2017; Kieslinger et al. 2019; Klein et al. 2014). Considering the frequency of reported impacts for each season in Savnob and Roshorv supports this argumentation (Fig. 4). Most impacts are reported in association with increasing autumn and winter temperatures. Whereas biophysical impacts and signs can be strong evidence for local changes in climate, their causes can be diverse. Therefore, scientists should aim to understand the sociocultural context where the information 
originated from. In Savnob and Roshorv, consent about warming temperatures in autumn and winter may be reinforced by a higher attention of the community members towards changes in their biophysical environment at this time of the year, as those seasons are important for local livelihoods and food systems. On the other side, less attention may be paid to indicators occurring in other seasons, which could explain the low consent about changes in summer temperature. Given the preceding argumentation, it came unexpected that decreasing levels of rain reached high consent in both communities. Neither is rain occurring frequently in the villages, due to semi-arid climate conditions, nor have many impacts been reported by the community members regarding rainfall events.

Whereas the reliability of community perceptions can differ between climate variables, the quality and substance of observations can also vary between community members (FernándezLlamazares et al. 2017). As individual viewpoints can be influenced by socioeconomic factors such as age, gender, or profession, we selected a homogenous group of participants in terms of age and profession to ensure a sound understanding of local climate and weather processes. Although, mean and women may perceive changes differently (Kalanda-Joshua et al. 2011), we did not enforce an equal gender distribution to respect local norms. Our results showed, that individual perceptions can be further influenced by existing daily routines of the respective communities. For example, community members of Roshorv experienced the availability of irrigation water differently (Fig. 4). As irrigation in Roshorv is strictly scheduled by an irrigation plan, it is likely, that individual perceptions of water availability may be influenced by the respondents' position in the order of irrigation. To enhance the quality of the research results, understanding the context where information originate from is essential for scientists. A further challenge in the analysis of peoples' perception of long-term climate trends, constitutes the influence of short-term weather fluctuations and extreme weather events (Reyes-García et al. 2016). In this study, we used historical time markers to help people anticipate long-term changes in climate. This method showed promising results as interviewees memorized the identified time period in the past and did not refer their answers to the last seasons or extreme events. However, to ensure the effectiveness of this method time markers have to be remembered by all community members and should appear in the form of time periods, rather than single years, to prevent seasonal biases. Whereas certain measures can be taken to enhance the reliability of community observations, a validation of the result, probably at a different time of the year than the initial stage of inquiry or with an independent sample, remain often missing in social science research. Due to time limitations a validation stage could not be included in this study but is strongly encouraged for future research.

\subsection{Cogeneration of knowledge across knowledge systems}

Cogenerating knowledge across different epistemologies is conceptually and methodologically challenging. Knowledge systems differ in their structure, values, and worldviews, and therefore entail their own strengths, limitations, and uncertainties (Aikenhead and Ogawa 2007; López et al. 2017). Against this background, we aimed to generate new information about local climate trends in the Pamirs by integrating instrumental climate data and community observations. Whereas our results showed different trend observations between both knowledge systems, we argue that both data types are highly complementary in detecting local climate trends in a peripheral mountain environment, as they (i) reduce existing uncertainties, (ii) provide new information, and (iii) introduce new perspectives. In terms of temperature, both knowledge systems provided information about seasonal 
temperature trends, however with different outcomes. ERA5 only showed a significant warming trend for summer, whereas community members identified autumn and winter as warming. Integrative studies in other regions also reported on different trend observations, which they argued with an existing scale mismatch between both knowledge systems (Fernández-Llamazares et al. 2017; Kieslinger et al. 2019). Whereas in our study a scale mismatch was prevented by downscaling ERA5 data to village-scale, the limited accuracy of the original ERA5 datasets due to missing insitu measurements still influences the spatial accuracy of downscaled temperature estimates and their significance measures. Community observations can reduce prevailing uncertainties by providing further evidences for local changes in temperature in the form of biophysical signs and indicators. Whereas those observations are limited in terms of objectivity and do not exist in the form of empirical, formal measurements, they are rooted and verified by daily observations and practices. Therefore, community observations can broaden the amount of available climate information at the site of specific villages and counteract prevailing uncertainties of instrumental data products.

In terms of snow, community observations and satellite data are highly complementary as they provide exclusive information about different snow variables. In peripheral areas, remote sensed products are often the only way to gain quantitative information about local snow patterns. However, those products perform better in estimating local snow cover extent than snow depth, if no in-situ measurements exist (Hoelzle et al. 2019). Resident communities on the other side, pay attention to other characteristics of snow. In the Pamirs, communities relate their observations to the amount of snow. In Norway, communities were shown to entail extensive knowledge about different types of snow (Riseth et al. 2011). Whereas both observations entail their limitations, such as uncertainties in satellite estimates due to cloud cover or missing standardized measurements by people, they can provide detailed information which cannot be gained using one knowledge system exclusively. Further, satellite images are generally restricted in the length of their observation period, providing data for the last two decades. Community observations can include generational or even trans-generational information about local snow characteristics. A combination of both knowledge systems can provide new and site-specific information about local snow characteristics. In the Pamirs, such information can have substantial benefits for predicting seasonal run-off regimes and subsequently the availability of drinking and irrigation water for local communities (UngerShayesteh et al. 2013).

\section{Conclusion}

The assessment of local climate trends in mountain environments constitutes a global research challenge. Uncertainty in climate data, which may result from a limited availability and temporal persistence of meteorological stations as well as coarse resolution gridded products, constrains the reliability of the conclusions drawn from such data sources. Therefore, it is of utmost importance for any locally adapted conclusions on climate change to reduce the uncertainty of the underlying data set. This study addresses this issue by integrating instrumental climate data and community observations on local climate trends in order to investigate complementarity. We applied a multi-method approach using downscaled ERA5 temperature data, the snow cover product MOD10A1 from MODIS, qualitative interviews, and community 
workshops. Seasonal trends in data from ERA5 and MOD10A1 were investigated using a statistical trend analysis. Shared pattern of knowledge in community observations on climate trends were identified using a consensus index. Our result showed that agropastoral communities in the Pamirs have deep-rooted knowledge of weather and climate which they derived from daily practices and long-term observations of their biophysical surroundings. Comparing communities' consent about local climate trends with instrumental climate records did not provide coinciding results. For temperature, instrumental climate data indicated an increasing trend in summer temperatures, whereas community observations identified a warming trend for autumn and winter. Discordant trend observations may essentially arise from multiple reasons, such as the statistical uncertainty in the downscaled temperature data or a seasonal bias in the communities' perception of climate trends. In terms of snow, both knowledge systems provided information about different snow parameter, which could not be derived by using one knowledge system exclusively. Community members reported on decreasing levels of snow, whereas satellite data demonstrated a shortening of the snow period in one of the villages. Indications for decreasing rainfall amounts could only be derived from community observations as local instrumental rainfall estimates are not available for the Pamirs.

Integrating data from independent knowledge systems is challenging, as knowledge systems differ in their structure and values, entailing their individual strengths and limitations. Given the high uncertainties of instrumental climate data in the Pamirs, we argue that community observations can reduce such uncertainties by providing new information about local climate trends. However, scientists have to carefully assess the context were human observations originate from to strengthen the reliability of such data. Establishing rapport and a respectful research relationship between scientists and local knowledge holders should be obligatory and acknowledged in the funding period of transdisciplinary research projects. Whereas this study was conducted in the Pamirs, the proposed approach can be transferred to other data-scarce, peripheral regions, such as the Himalaya, Andes, or rural parts of Africa, where traditional communities share a strong connectivity with their biophysical habitat. Further, integrated results from different knowledge systems at the scale of individual villages can provide valuable information for local climate adaptation or impact studies.

Supplementary Information The online version contains supplementary material available at https://doi.org/ 10.1007/s10584-021-02988-3.

\begin{abstract}
Acknowledgements First, this work would not have been possible without the contributions from the communities of Savnob and Roshorv. We wish to thank those communities for their trust, insights and experiences they shared with us. Special thanks to Mr. Umed Bulbulshoev for supporting this research in terms of logistics, translation, workshop organisation, and for always taking care. We gratefully acknowledge that this research was funded by the Belmont Forum and German Research Foundation (grant number SA 775/12-1). Also, thank you to all the team members of the ECCAP project, who contributed with their expertise and company to the success of all field sessions and the development of this study. Special thanks to Prof. Thomas Mölg, who helped developing the best strategy to gain village scale temperature data. Thank you to Julia Blauhut for her graphical work on the figures in this paper. We thank two anonymous reviewers for their time and constructive and valuable comments and suggestions.
\end{abstract}

Code availability Not applicable

Funding This research was funded by the Belmont Forum and German Research Foundation (grant number SA 775/12-1). Open Access funding enabled and organized by Projekt DEAL. 
Data availability Not applicable

\section{Declarations}

Conflict of interest The authors declare that they have no conflict of interest.

Open Access This article is licensed under a Creative Commons Attribution 4.0 International License, which permits use, sharing, adaptation, distribution and reproduction in any medium or format, as long as you give appropriate credit to the original author(s) and the source, provide a link to the Creative Commons licence, and indicate if changes were made. The images or other third party material in this article are included in the article's Creative Commons licence, unless indicated otherwise in a credit line to the material. If material is not included in the article's Creative Commons licence and your intended use is not permitted by statutory regulation or exceeds the permitted use, you will need to obtain permission directly from the copyright holder. To view a copy of this licence, visit http://creativecommons.org/licenses/by/4.0/.

\section{References}

Abu R, Reed MG, Jardine TD (2019) Using two-eyed seeing to bridge Western science and Indigenous knowledge systems and understand long-term change in the Saskatchewan River Delta, Canada. International Journal of Water Resources Development 23:1-20. https://doi.org/10.1080/07900627.2018. 1558050

Aikenhead GS, Ogawa M (2007) Indigenous knowledge and science revisited. Cult Stud of Sci Educ 2:539-620. https://doi.org/10.1007/s11422-007-9067-8

Aizen VB, Aizen EM, Kuzmichenok VA (2007) Geo-informational simulation of possible changes in Central Asian water resources. Global and Planetary Change 56:341-358. https://oi.org/10.1016/j.gloplacha.2006. 07.020

Aizen EM, Aizen VB, Melack JM, Nakamura T, Ohta T (2001) Precipitation and atmospheric circulation patterns at mid-latitudes of Asia. Int. J. Climatol. 21:535-556. https://doi.org/10.1002/joc.626

Alexander C, Bynum N, Johnson E, King U, Mustonen T, Neofotis P, Oettlé N, Rosenzweig C, Sakakibara C, Shadrin V, Vicarelli M, Waterhouse J, Weeks B (2011) Linking Indigenous and Scientific Knowledge of Climate Change. BioScience 61:477-484. https://doi.org/10.1525/bio.2011.61.6.10

Ayanlade A, Radeny M, Morton JF (2017) Comparing smallholder farmers' perception of climate change with meteorological data: A case study from southwestern Nigeria. Weather and Climate Extremes 15:24-33. https://doi.org/10.1016/j.wace.2016.12.001

Boillat S, Berkes F (2013) Perception and Interpretation of Climate Change among Quechua Farmers of Bolivia: Indigenous Knowledge as a Resource for Adaptive Capacity. E\&S 18. https://doi.org/10.5751/ES-05894180421

Brubaker KL, Pinker RT, Deviatova E (2005) Evaluation and Comparison of MODIS and IMS Snow-Cover Estimates for the Continental United States using Station Data. Journal of Hydrometeorology 6

Byg A, Salick J (2009) Local perspectives on a global phenomenon - Climate change in Eastern Tibetan villages. Global Environmental Change 19:156-166. https://doi.org/10.1016/j.gloenvcha.2009.01.010

Chaudhary P, Bawa KS (2011) Local perceptions of climate change validated by scientific evidence in the Himalayas. Biol Lett 7:767-770. https://doi.org/10.1098/rsbl.2011.0269

Chen F, Wang J, Jin L, Zhang Q, Li J, Chen J (2009) Rapid warming in mid-latitude central Asia for the past 100 years. Front. Earth Sci. China 3:42-50. https://doi.org/10.1007/s11707-009-0013-9

Choi G, Robinson DA, Kang S (2010) Changing Northern Hemisphere Snow Seasons. J. Climate 23:5305-5310. https://doi.org/10.1175/2010JCLI3644.1

Crawford CJ (2015) MODIS Terra Collection 6 fractional snow cover validation in mountainous terrain during spring snowmelt using Landsat TM and ETM+. Hydrol. Process. 29:128-138. https://doi.org/10.1002/hyp. 10134

Copernicus Climate Change Service (C3S) (2017) ERA5: Fifth generation of ECMWF atmospheric reanalyses of the global climate. Copernicus Climate Change Service (CDS), https://cds.climate.copernicus.eu/cdsapp\# !/home

Cuerrier A, Brunet ND, Gérin-Lajoie J, Downing A, Lévesque E (2015) The Study of Inuit Knowledge of Climate Change in Nunavik, Quebec: A Mixed Methods Approach. Hum Ecol 43:379-394. https://doi.org/ $10.1007 / \mathrm{s} 10745-015-9750-4$ 
Dietz A, Conrad C, Kuenzer C, Gesell G, Dech S (2014) Identifying Changing Snow Cover Characteristics in Central Asia between 1986 and 2014 from Remote Sensing Data. Remote Sensing 6(12):12752-12775

Fernández-Llamazares Á, Garcia RA, Díaz-Reviriego I, Cabeza M, Pyhälä A, Reyes-García V (2017) An empirically tested overlap between indigenous and scientific knowledge of a changing climate in Bolivian Amazonia. Reg Environ Change 17:1673-1685. https://doi.org/10.1007/s10113-017-1125-5

Finaev A, Shiyin L, Weijia B, Li J (2016) Climate change and water potential of the Pamir Mountains. GES 9: 88-105. https://doi.org/10.15356/2071-9388 03v09 201606

Ford J, Cameron L, Rubis J, Maillet M, Nakashima D, Willox AC, Pearce T (2016) Including indigenous knowledge and experience in IPCC assessment reports. Nature Clim Change 6

Gafurov A, Bárdossy A (2009) Cloud removal methodology from MODIS snow cover product. Hydrology and Earth System Sciences 13:1361-1373

Gafurov A, Kriegel D, Vorogushyn S, Merz B (2013) Evaluation of remotely sensed snow cover product in Central Asia. Hydrology Research 44:506-522. https://doi.org/10.2166/nh.2012.094

Gao L, Bernhardt M, Schulz K (2012) Elevation correction of ERA-Interim temperature data in complex terrain. Hydrol. Earth Syst. Sci. 16:4661-4673. https://doi.org/10.5194/hess-16-4661-2012

Gao L, Bernhardt M, Schulz K, Chen X (2017) Elevation correction of ERA-Interim temperature data in the Tibetan Plateau. Int. J. Climatol. 37:3540-3552. https://doi.org/10.1002/joc.4935

García-Del-Amo D, Mortyn PG, Reyes-García V (2020) Including Indigenous and local knowledge in climate research. An assessment of the opinion of Spanish climate change researchers. Climatic Change 160:67-88. https://doi.org/10.1007/s10584-019-02628-X

Gascoin S, Hagolle O, Huc M, Jarlan L, Dejoux J-F, Szczypta C, Marti R, Sánchez R (2015) A snow cover climatology for the Pyrenees from MODIS snow products. Hydrol. Earth Syst. Sci. 19:2337-2351. https:// doi.org/10.5194/hess-19-2337-2015

Gearheard S, Pocernich M, Stewart R, Sanguya J, Huntington HP (2010) Linking Inuit knowledge and meteorological station observations to understand changing wind patterns at Clyde River, Nunavut. Climatic Change 100:267-294. https://doi.org/10.1007/s10584-009-9587-1

Gentle P, Maraseni TN (2012) Climate change, poverty and livelihoods: adaptation practices by rural mountain communities in Nepal. Environmental Science \& Policy 21:24-34. https://doi.org/10.1016/j.envsci.2012.03. 007

Gerlitz L, Conrad O, Thomas A, Böhner J (2014) Warming patterns over the Tibetan Plateau and adjacent lowlands derived from elevation- and bias-corrected ERA-Interim data. Clim. Res. 58:235-246. https://doi. org/10.3354/cr01193

Green D, Billy J, Tapim A (2010) Indigenous Australians' knowledge of weather and climate. Climatic Change 100:337-354. https://doi.org/10.1007/s10584-010-9803-z

Haag I, Jones PD, Samimi C (2019) Central Asia's Changing Climate: How Temperature and Precipitation Have Changed across Time, Space, and Altitude. Climate 7:123. https://doi.org/10.3390/cli7100123

Hall DK, Riggs GA (2016) MODIS/Terra Snow Cover Daily L3 Global 500m SIN Grid, Version 6 [MOD10A1], Boulder, Colorado USA. https://nsidc.org/data/MOD10A1/versions/6

Hall DK, Riggs GA (2007) Accuracy assessment of the MODIS snow products. Hydrol. Process. 21:1534-1547. https://doi.org/10.1002/hyp.6715

Hall DK, Riggs GA, DiGirolamo NE, Román MO (2019) MODIS Cloud-Gap Filled Snow-Cover Products: Advantages and Uncertainties. Hydrol. Earth Syst. Sci. https://doi.org/10.5194/hess-2019-123

Hersbach H, de Rosnay P, Bell B, Schepers D, Simmons A, Soci C, Abdalla S, Alonso Balmaseda M, Balsamo G, Bechtold P, Berrisford P, Bidlot J, de Boisséson E, Bonavita M, Browne P, Buizza R, Dahlgren P, Dee D, Dragani R, Diamantakis M, Flemming J, Forbes R, Geer A, Haiden T, Hólm E, Haimberger L, Hogan R, Horányi A, Janisková M, Laloyaux P, Lopez P, Muñoz-Sabater J, Peubey C, Radu R, Richardson D, Thépaut J-N, Vitart F, Yang X, Zsótér E, Zuo H (2018) Operational global reanalysis: progress, future directions and synergies with NWP. ECMWF Report Series

Hoelzle M, Barandun M, Bolch T, Fiddes J, Gafurov A, Muccione V, Saks T, Shahgedanova M (2019) The status and role of the alpine cryosphere in Central Asia. In: Xenarios S, Schmidt-Vogt D, Janusz-Pawletta B, Abdullaev I (eds) The Aral Sea basin. Water for sustainable development in Central Asia, pp 100-121

Hu Z, Zhang C, Hu Q, Tian H (2014) Temperature Changes in Central Asia from 1979 to 2011 Based on Multiple Datasets. Journal of Climate 27:1143-1167. https://doi.org/10.1175/JCLI-D-13-00064.s1

$\mathrm{Hu}$ Z, Hu Q, Zhang C, Chen X, Li Q (2016) Evaluation of reanalysis, spatially interpolated and satellite remotely sensed precipitation data sets in central Asia. J. Geophys. Res. Atmos. 121:5648-5663. https://doi.org/10. 1002/2016JD024781

Ifejika Speranza C, Kiteme B, Ambenje P, Wiesmann U, Makali S (2010) Indigenous knowledge related to climate variability and change: insights from droughts in semi-arid areas of former Makueni District, Kenya. Climatic Change 100:295-315. https://doi.org/10.1007/s10584-009-9713-0 
Ingty T (2017) High mountain communities and climate change: adaptation, traditional ecological knowledge, and institutions. Climatic Change 145:41-55. https://doi.org/10.1007/s10584-017-2080-3

Jain SK, Goswami A, Saraf AK (2008) Accuracy assessment of MODIS, NOAA and IRS data in snow cover mapping under Himalayan conditions. International Journal of Remote Sensing 29:5863-5878. https://doi. org/10.1080/01431160801908129

Kalanda-Joshua M, Ngongondo C, Chipeta L, Mpembeka F (2011) Integrating indigenous knowledge with conventional science: Enhancing localised climate and weather forecasts in Nessa, Mulanje, Malawi. Physics and Chemistry of the Earth, Parts A/B/C 36:996-1003. https://doi.org/10.1016/j.pce.2011.08.001

Kassam K-A, Bulbulshoev U, Ruelle M (2011) Ecology of Time: Calendar of the Human Body in the Pamir Mountains. J Persianate Stud 4:146-170. https://doi.org/10.1163/187471611X600369

Kassam K-AS, Ruelle ML, Samimi C, Trabucco A, Xu J (2018) Anticipating Climatic Variability: The Potential of Ecological Calendars. Hum Ecol Interdiscip J 46:249-257. https://doi.org/10.1007/s10745-018-9970-5

Kendall M (1975) Rank Correlation Methods, fourth edn. Charles Griffin \& Company LTD, London and High Wycombe

Kieslinger J, Pohle P, Buitrón V, Peters T (2019) Encounters Between Experiences and Measurements: The Role of Local Knowledge in Climate Change Research. Mountain Research and Development 39. https://doi.org/ 10.1659/MRD-JOURNAL-D-18-00063.1

King DNT, Skipper A, Tawhai WB (2008) Māori environmental knowledge of local weather and climate change in Aotearoa - New Zealand. Climatic Change 90:385-409. https://doi.org/10.1007/s10584-007-9372-y

Klein JA, Hopping KA, Yeh ET, Nyima Y, Boone RB, Galvin KA (2014) Unexpected climate impacts on the Tibetan Plateau: Local and scientific knowledge in findings of delayed summer. Global Environmental Change 28:141-152. https://doi.org/10.1016/j.gloenvcha.2014.03.007

Kohler T, Giger M, Hurni H, Ott C, Wiesmann U, Wymann von Dach S, Maselli D (2010) Mountains and Climate Change: A Global Concern. Mountain Research and Development 30:53-55. https://doi.org/10. 1659/MRD-JOURNAL-D-09-00086.1

Li C, Su F, Yang D, Tong K, Meng F, Kan B (2018) Spatiotemporal variation of snow cover over the Tibetan Plateau based on MODIS snow product, 2001-2014. International Journal of Climatology 38(2):708-728

Lievens H, Demuzere M, Marshall H-P, Reichle RH, Brucker L, Brangers I, Rosnay P de, Dumont M, Girotto M, Immerzeel WW, Jonas T, Kim EJ, Koch I, Marty C, Saloranta T, Schöber J, Lannoy GJM de (2019) Snow depth variability in the Northern Hemisphere mountains observed from space. Nat Commun 10:4629. https://doi.org/10.1038/s41467-019-12566-y

López S, Jung J-K, López MF (2017) A hybrid-epistemological approach to climate change research: Linking scientific and smallholder knowledge systems in the Ecuadorian Andes. Anthropocene 17:30-45. https://doi. org/10.1016/j.ancene.2017.01.001

Manandhar S, Xenarios S, Schmidt-Vogt D, Hergarten C, Foggin M (2018) Climate Vulnerability and Adaptive Capacity of Mountain Societies in Central Asia. Research Report 1, Mountain Societies Research Institute, University of Central Asia

Mann HB (1945) Nonparametric Tests Against Trend. Econometrica 13:245-259

Meze-Hausken E (2004) Contrasting climate variability and meteorological drought with perceived drought and climate change in northern Ethiopia. Climate Research 27:19-31

R Core Team (2018) R: A language and environment for statistical computing. R Foundation for Statistical Computing, Vienna, Austria https://www.R-project.org

Rapinski M, Payette F, Sonnentag O, Herrmann TM, Royer M-JS, Cuerrier A, Siegwart Collier L, Hermanutz L, Guanish G (2018) Listening to Inuit and Naskapi peoples in the eastern Canadian Subarctic: a quantitative comparison of local observations with gridded climate data. Reg Environ Change 18:189-203. https://oi. org/10.1007/s10113-017-1188-3

Reyes-García V, Fernández-Llamazares Á, Guèze M, Garcés A, Mallo M, Vila-Gómez M, Vilaseca M (2016) Local indicators of climate change: the potential contribution of local knowledge to climate research. Wiley Interdisciplinary Reviews: Climate Change 7:109-124. https://doi.org/10.1002/wcc.374

Riggs GA, Hall DK, Román MO (2016) MODIS Snow Products Collection 6 User Guide

Riseth JÅ, Tømmervik H, Helander-Renvall E, Labba N, Johansson C, Malnes E, Bjerke JW, Jonsson C, Pohjola V, Sarri L-E, Schanche A, Callaghan TV (2011) Sámi traditional ecological knowledge as a guide to science: snow, ice and reindeer pasture facing climate change. Polar Record 47:202-217. https://doi.org/10.1017/ S0032247410000434

Romney AK, Weller SC, Batchhelder WH (1986) Culture as Consensus: A Theory of Culture and Informant Accuracy. American Anthropologist 88:313-338

Sen PK (1968) Estimates of the Regression Coefficient Based on Kendall's Tau. Journal of the American Statistical Association 63:1379-1389. https://doi.org/10.1080/01621459.1968.10480934 
Simelton E, Quinn CH, Batisani N, Dougill AJ, Dyer JC, Fraser ED, Mkwambisi D, Sallu S, Stringer LC (2013) Is rainfall really changing? Farmers' perceptions, meteorological data, and policy implications. Climate and Development 5:123-138. https://doi.org/10.1080/17565529.2012.751893

State Administration for Hydrometeorology of the Republic of Tajikistan (2013) Climatic dataset for the Pamir Region acquired from the Tajik hydrometeorological service, Dushanbe

Theil H (1950) A rank-invariant method of linear and polynomial regression analysis. Part 3. Nederlandse Akademie Van Wetenschappen 53:1397-1412

Unger-Shayesteh K, Vorogushyn S, Farinotti D, Gafurov A, Duethmann D, Mandychev A, Merz B (2013) What do we know about past changes in the water cycle of Central Asian headwaters? A review. Global and Planetary Change 110:4-25. https://doi.org/10.1016/j.gloplacha.2013.02.004

Williams P, Alessa L, Abatzoglou J, Kliskey A, Witmer F, Lee O, Trammell J, Beaujean G, Venema R (2018) Community-based observing networks and systems in the Arctic: Human perceptions of environmental change and instrument-derived data. Reg Environ Change 18:547-559. https://doi.org/10.1007/s10113-0171220-7

Woodward E (2010) Creating the Ngan'gi seasons calendar: Reflections on engaging Indigenous knowledge authorities in research. In: Christie M, Verran H (eds) Learning Communities: International Journal of Learning in Social Contexts, vol 2010

Xenarios S, Gafurov A, Schmidt-Vogt D, Sehring J, Manandhar S, Hergarten C, Shigaeva J, Foggin M (2019) Climate change and adaptation of mountain societies in Central Asia: uncertainties, knowledge gaps, and data constraints. Reg Environ Change 19:1339-1352. https://doi.org/10.1007/s10113-018-1384-9

Zahumenský I (2004) Guidelines on Quality Control Procedures for Data from Automatic Weather Station, Geneva, Switzerland

Zandler H, Haag I, Samimi C (2019) Evaluation needs and temporal performance differences of gridded precipitation products in peripheral mountain regions. Sci Rep 9:15118. https://doi.org/10.1038/s41598019-51666-Z

Publisher's note Springer Nature remains neutral with regard to jurisdictional claims in published maps and institutional affiliations.

\section{Affiliations}

\section{Isabell Haag ${ }^{1} \cdot$ Karim-Aly Kassam $^{2} \cdot$ Thomas Senft $^{1} \cdot$ Harald Zandler $^{1,3} \cdot$ Cyrus Samimi ${ }^{1,3}$}

Karim-Aly Kassam

ksk28@cornell.edu

Thomas Senftl

thomas.senftl@tum.de

Harald Zandler

harald.zandler@uni-bayreuth.de

Cyrus Samimi

cyrus.samimi@uni-bayreuth.de

1 Working Group of Climatology, Universität Bayreuth, 95448 Bayreuth, Germany

2 Department of Natural Resources, Cornell University, Ithaca, New York, USA

3 Bayreuth Center of Ecology and Environmental Research, 95448 Bayreuth, Germany 